\title{
CHANGES IN THE HEAVY METAL CONTENT IN RIVER ALLUVIA OF LOWER VISTULA DURING THE LAST 100 YEARS $^{1}$
}

Changes in the state of the natural environment can be easily observed in riverbeds (and their closest vicinity), where water transport along with the sediments originating from the whole respective catchment area is taking place. Economic activity of man, such as extraction and processing of useful minerals (ores), industrial production, waste dumping, or finally the very functioning of towns, causes that the amounts of waste discharged to rivers may often exceed the self-purification capacities. In the $20^{\text {th }}$ century, in parallel with the intensive development of industry, urbanisation, and general population growth, the volume of noxious substances discharged to the river system abruptly increased.

Heavy metals (trace elements) may find their way to river beds either due to natural geological processes, like weathering (their natural contents in various sediments constitutes the geochemical background) or due to the economic activity of man. Last century (and for some areas - the last several hundred years) has been characterised by the anthropogenic input which has been many times higher than the natural one (see, in particular, Klimek, 1994, 1996; Helios-Rybicka, 1986).

Trace elements, which are found in river waters, such as $\mathrm{Cu}, \mathrm{Cd}, \mathrm{Pb}, \mathrm{Zn}$, Co, etc., are quickly accumulated in the river bed sediments and outside of the river bed, in particular owing to co-precipitation and deposition of the insoluble substances as well as sorption by the loamy minerals or organic substance being the components of the river suspension (Salomons, 1995; Helios-Rybicka, 1986). The growth of industry and urbanisation in the last century brought an increased input of heavy metals to river beds. Heavy metal content in river sediments depends upon the length of transport route from the source of pollution, and may change also due to variation in the intensity of discharge. The accumulated river deposits preserve the record of history of heavy metal input having originated from various pollution sources (Szwarczewski, 1997; Sokołowska, Szwarczewski, 1998).

${ }^{1}$ The paper is the result of studies conducted in the framework of the research project of the Polish Committee for Scientific Research (KBN) no. 6PO4E 01916. 
In the opinion of a majority of scholars the mobility of heavy metals depends upon the value of $\mathrm{pH}$, redox potential, dissolved oxygen, or salinity. Due to the disadvantageous chemical transformations within the polluted deposits a secondary contamination may take place, owing, in particular, to the migration of the trace elements to water - such cases are known for marine deposits (Salomons, 1995), or as a result of re-deposition of the contaminated deposits (Klimek, Macklin, 1991; Ciszewski, 1999). Heavy metals accumulated along with the alluvial deposits are, in view of the nature of binding (carbonate buffer), characterised by weak mobility, and their accelerated migration is possible only with a change of $\mathrm{pH}$ down to some $2-3$. In natural conditions their complete liberation is possible in, for instance, the case of the sandy soils featuring high infiltration only after at least 1000 years (Salomons, 1995).

An important problem in the analysis of contamination of alluvial deposits with heavy metals consists in determination of their age and sedimentation conditions. For this purpose, archival topographical maps can be used (see, e.g., Florek, Nadaczna, 1986; Koc, 1972; Szumański, 1982; Trafas, 1975). On the basis of the drawing showing the coastal line of the river from the successive editions of topographical maps quantitative data can be obtained defining, in particular, the rate of river erosion (Hooke, 1977; Szwarczewski, 1987; Sokołowska, Szwarczewski, 1998). These segments of the river bed, which feature a constant increase of the deposited alluvia, are most appropriate for the analysis of the age of deposits. The changes of the river channel course (determined on the basis of the archival topographical maps) may take place due to natural fluvial processes (Fig. 1) or can be the effect of human activity (like damming up of Vistula river in Włocławek Fig. 2, or river regulation works downstream of Silno).

On the basis of the analysis of cartographic material five cross-sections were selected, in which altogether 24 dig-ins were made and 88 deposit samples taken (the total of some 1000 various measurements were done). Locations of the cross-sections are shown in Figs. 3 through 6 . The places in which dig-ins were made were located so as to include the deposits accumulated in the periods between the consecutive editions of the maps.

The samples of deposits were taken from the contemporary outwashes, from the dig-ins made within the lower terraces, the uncovered areas in bank cliffs, and with the use of the so-called Kajak's sampler (Kajak et al., 1965) from the bottom of Włocławek Reservoir. Samples were taken from diverse genetic levels, distinguished through colour and the particle sizes of the deposits.

The cores of the bottom sediments from the Włocławek Reservoir, taken with the sampler, were divided into segments of $5 \mathrm{~cm}$ of thickness. Samples were taken from locations satisfying the condition of continuity of sedimentation (Fig. 6).

The heavy metal contents were measured in the sediments taken in the fraction of less than $0.063 \mathrm{~mm}$. Extraction was carried out in the mixture of 


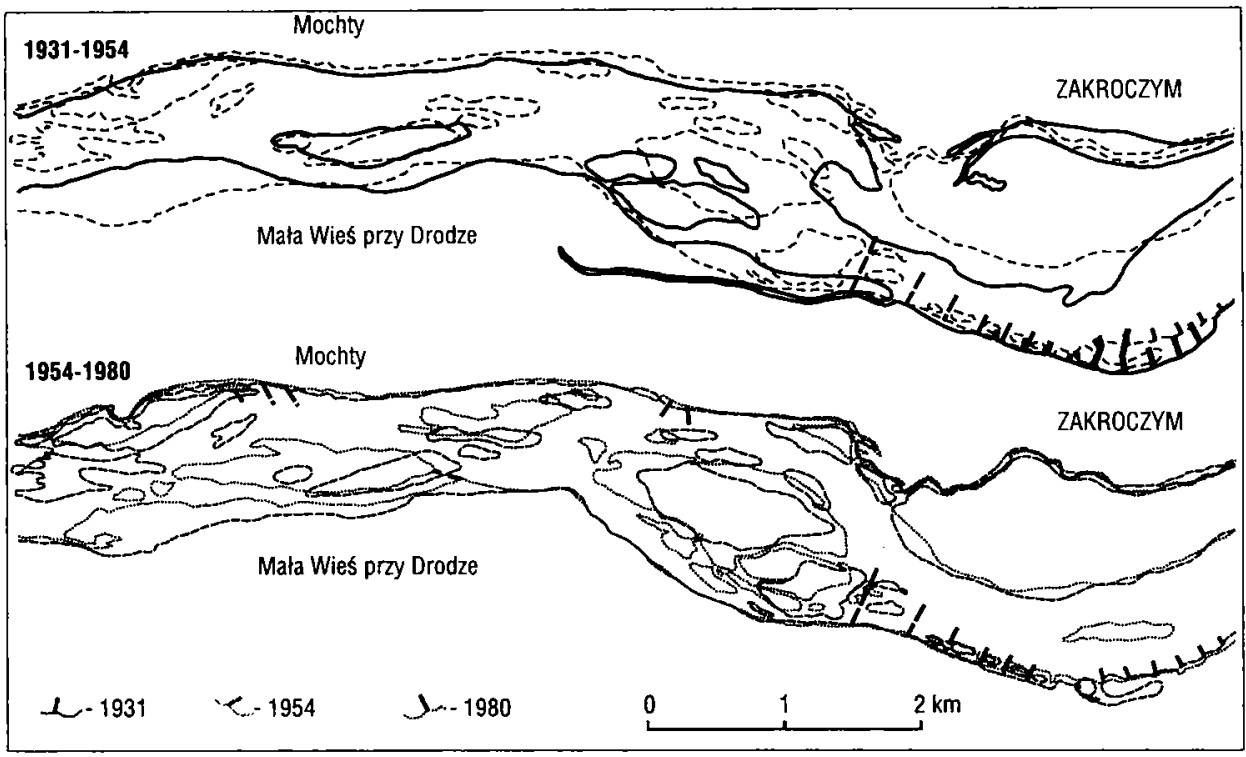

Fig. 1. Location of the image of Vistula river channel in the years 1931, 1954 and 1980.

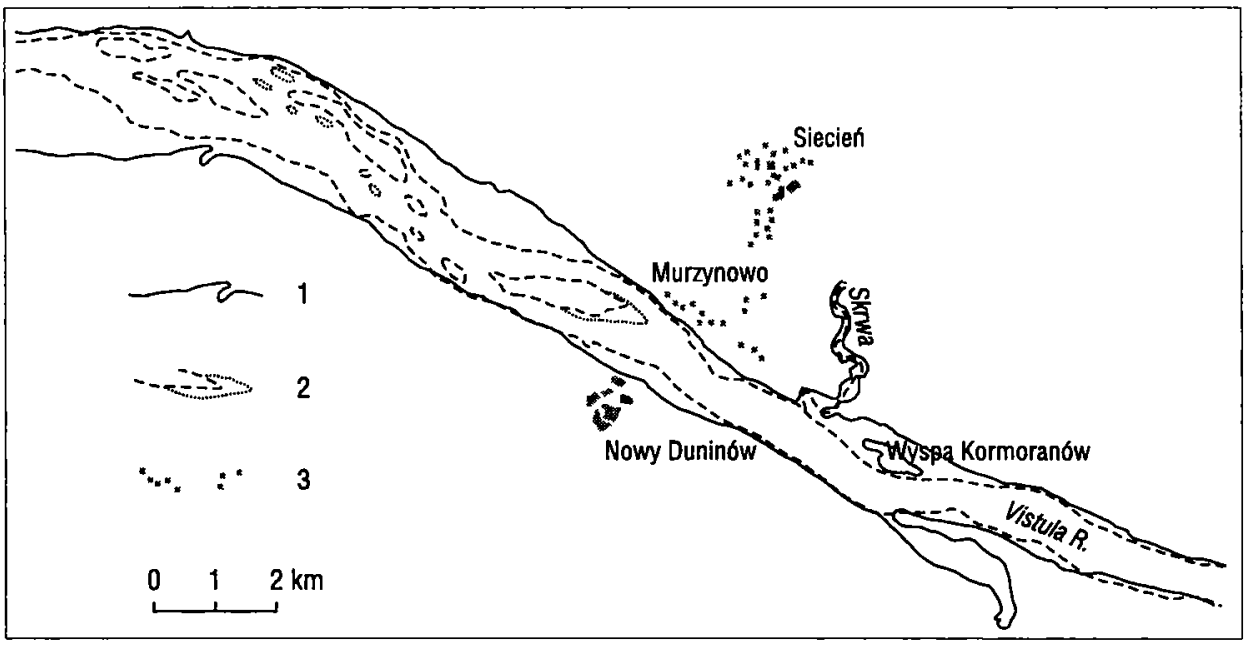

Fig. 2. Changes in the river bed of Vistula after creation of Whoclawek Reservoir 1 - location of the river bed image in 1991, 2 - location of the river bed image in 1931, 3 settlements.

the concentrated hydrofluoric acid $(1 \mathrm{ml})$ and nitric acid, using the microwave system. The trace elements analysed were measured with the method of atomic absorptive spectroscopy (AAS).

The results of analysis of heavy metal contents in the samples considered were related to the geochemical background, constituted for the segment of 
Vistula river in question by the metal contents in the older Pleistocene deposits. The geochemical background values for particular elements were as follows: $\mathrm{Cu}-6-15 \mathrm{ppm}, \mathrm{Cd}-0-0.2 \mathrm{ppm}, \mathrm{Pb}-5-10 \mathrm{ppm}$, and $\mathrm{Zn}-$ 30-70 ppm.

The highest heavy metal concentrations in the currently deposited alluvia of Vistula river between Wyszogród and Torun were observed in the sediments of Włoclawek Reservoir and its backwaters, while the distinctly increased concentrations in relation to geochemical background were noted downstream of Warsaw and in the vicinity of Wyszogród - at the mouth of the contaminated river Bzura, draining an industrial area (Fig. 3). The change of dynamics of the river between Kępa Polska and the Włocławek dam leads to a forced accumulation of the contaminated deposits brought by the river, so that in the upper segment of the reservoir thicker deposits accumulate, while in the middle and lower segments - the finer, loamy and dusty deposits accumulate, carrying the major part of pollution (Banach, 1985).

The changes of concentration of heavy metals in the cross section of the flood plain and the riverbed of Vistula constitute the evidence for the different volumes of the accumulated (and so also transported) heavy metals during the $20^{\text {th }}$ century. Fig. 4 presents in a general manner the range of variability of heavy metal contents in the particular cross sections analysed (between Warsaw and Toruń). The profiles, in which there is a significant difference between the maximum and minimum values, indicate the locations characterised by the biggest variability of input from local pollution sources (like the vicinity of Nowa Wieś przy Drodze, Wyszogród, Bobrowniki, and Brzoza Toruńska). An example of the distribution of concentrations of some heavy metals $(\mathrm{Pb}, \mathrm{Zn})$ in the transversal profile encompassing the eroded bank and the bank characterised by the persistent lateral increment of alluvia is shown in Fig. 5. The decrease of concentration of heavy metals along with the increasing distance from the contemporary river bed, and with increasing depth has been observed. The deposits of the Vistula river, as it flows nowadays, are characterised by the significantly lower heavy metal contents in comparison with the deposits formed in the years 19601970.

An interesting regularity was observed in the concentration of heavy metals in the bottom sediments of the Wlocławek Reservoir, deposited on the former flood terrace, now a part of the reservoir's bottom. The decidedly higher concentrations of trace elements were observed there in the lower (older) parts of the cores (between 15 and $25 \mathrm{~cm}$ ) than in the upper (younger) parts (see Fig. 6). The average thickness of deposits in the areas inundated after the dam had been built was $0.2-0.3 \mathrm{~m}$, and hence the present author presumes that the higher concentration of heavy metals in the floor part of sedimentation in the reservoir is connected with accumulation of the contaminated deposits during filling of the Whocławek Reservoir, that is - at the end of the 1960s and the beginning of 1970s. A distinct change in 


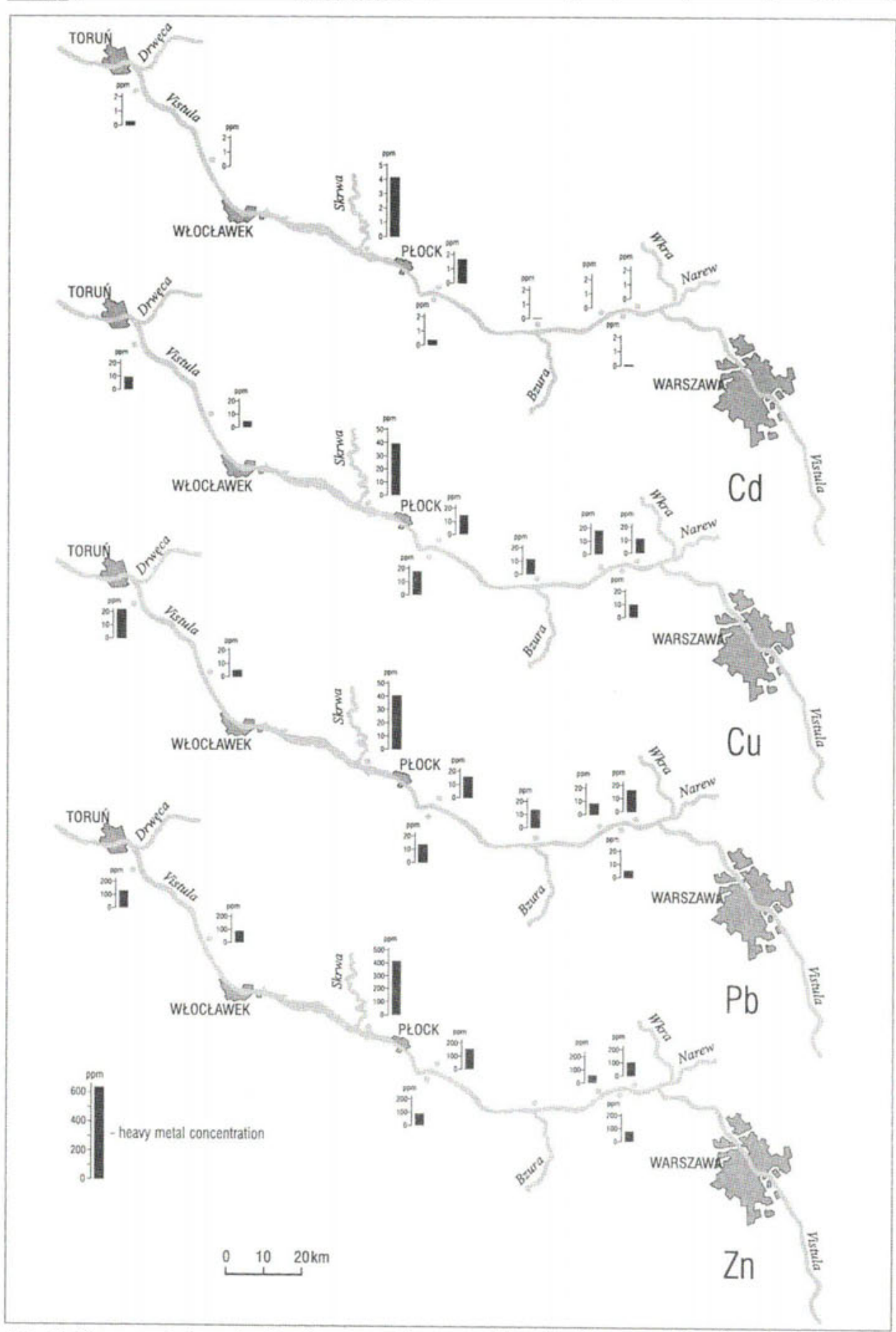

Fig. 3. Heavy metal content in the currently accumulated sediments of the Vistula river. 


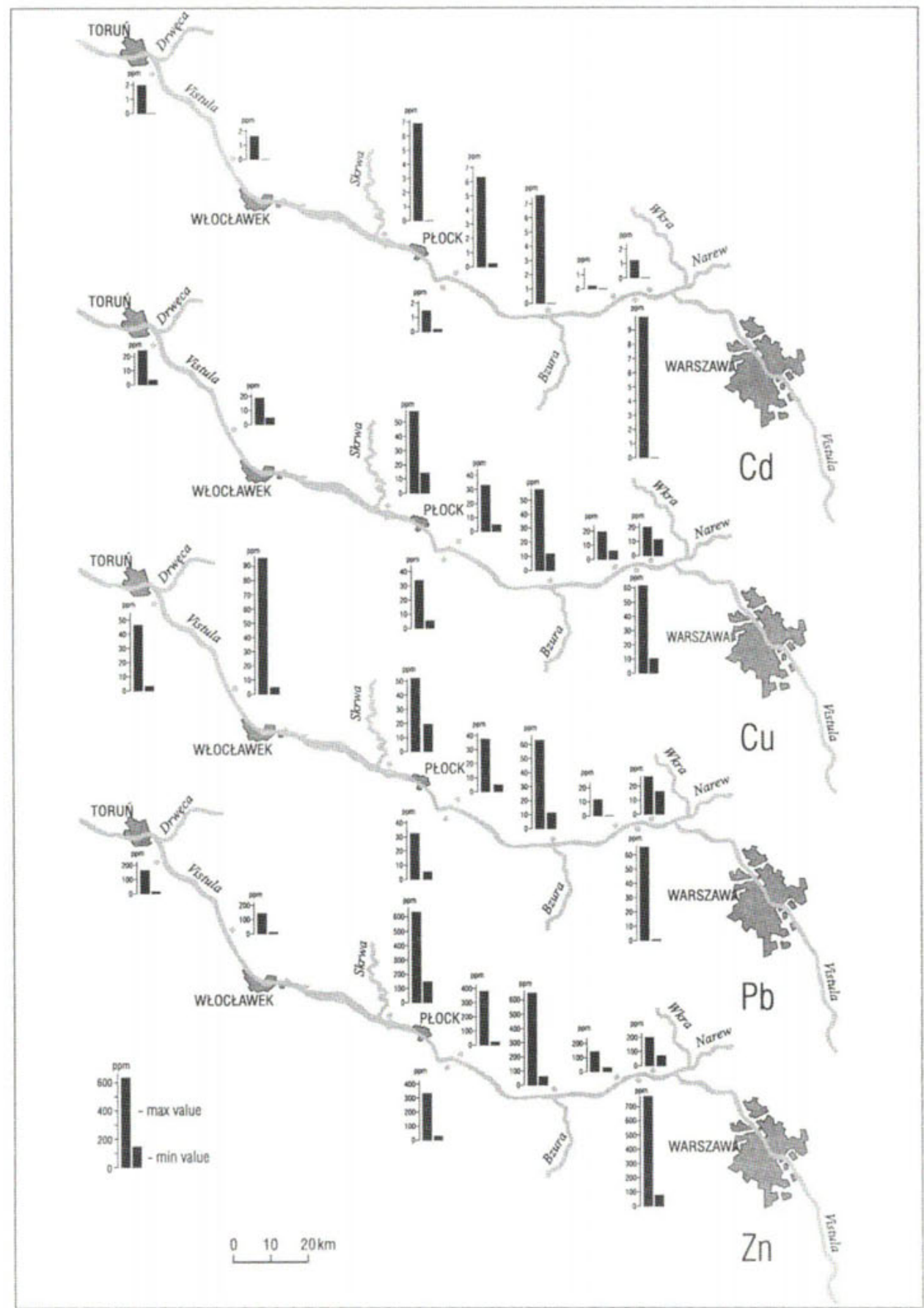

Fig. 4. Extreme values of heavy metal concentrations in the deposits of Vistula river accumulated in the $20^{\text {th }}$ century 


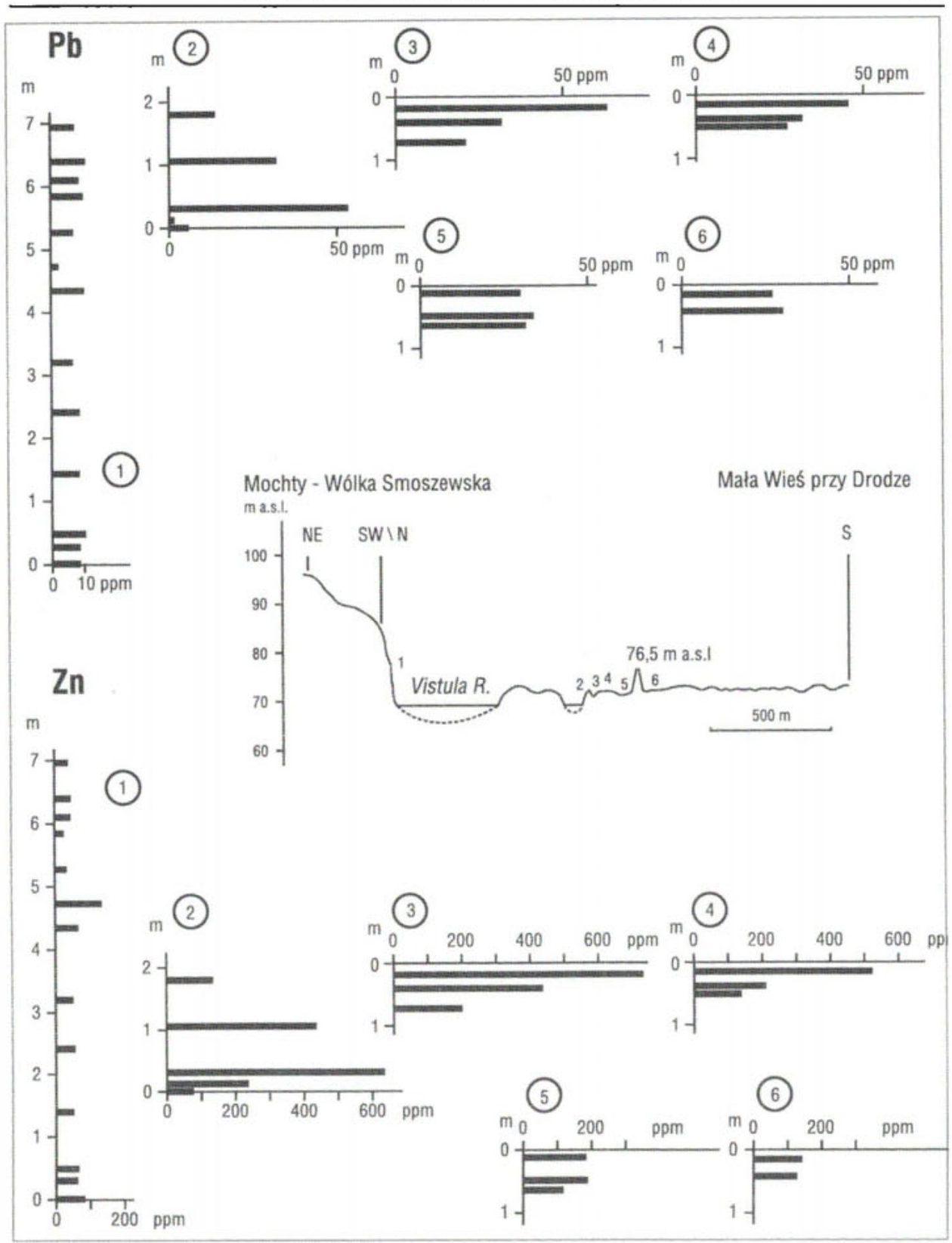

Fig. 5. Contents of $\mathrm{Pb}$ and $\mathrm{Zn}$ in the Vistula river alluvia accumulated during the $20^{\text {th }}$ century in the vicinity of Mochty and Nowa Wieś przy Drodze. 


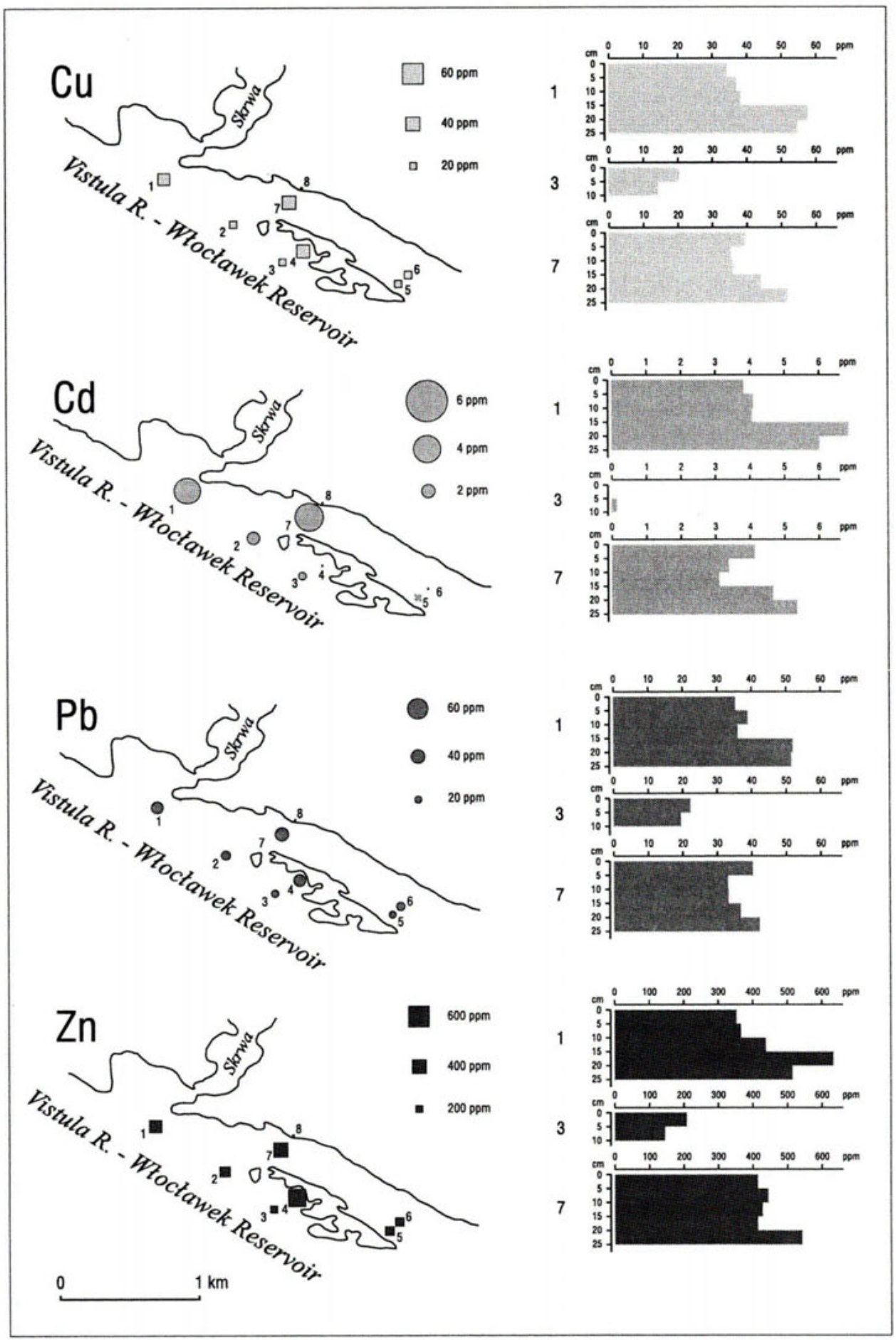


throughflow dynamics occurred at that time, and this, in turn, brought an accelerated accumulation of deposits. It should be added that in all the samples of sediments taken from the Włocławek Reservoir the concentrations of heavy metals exceed several times the geochemical background.

Observation of the heavy metal content in alluvial deposits of various age allows to formulate the following regularities:

- the highest concentration of metals is observed in the deposits accumulated in the 1960s and 1970s;

- in case of growing lateral outwashes the concentrations of heavy metals decreases along with the depth and distance from the river bed, indicating the increasing contamination of the whole fluvial environment over the last 70 years;

- the lower heavy metal concentrations in the alluvial deposits located outside of the flood protection dykes demonstrate their significance also for environmental protection;

- river deposits accumulated during last few years, in particular in the vicinity of Mochty, are characterised by the lower concentration of trace elements in comparison with the maximum values, which must be associated with the improvement in the state of the environment in the basin of Vistula;

- the river downstream of the Włocławek dam transports deposits featuring low concentrations of heavy metals, similar to those of the geochemical background; a comparison of the trace element contents in the deposits accumulated upstream from, within, and downstream from the Whocławek Reservoir leads to the conclusion that along with sedimentation of fine deposits at the bottom, accumulation of a heavy load of contaminants is taking place.

\section{REFERENCES}

B a nach M., 1985, Osady denne - wskanik hydrodynamiki zbiornika włocławskiego [Bottom deposits - the indicator of hydrodynamics of the Wlocławek Reservoir], Przegl. Geogr., LVII, 4.

C is z ew ski D., 1999, Przekształcenia fluwialnego systemu sedymentacyjnego wskutek eksploatacji rud metali [Transformations of the fluvial sedimentation system due to metal ore extraction], Czasopismo Geograficzne, LXX, 1.

Florek W., Nadaczna E., 1986, Zmiany biegu Parsęty i Wieprzy w ciągu ostatnich dwustu lat $w$ świetle analizy materiałów kartograficznych [Changes in the course of Parsęta and Wieprza rivers during the last two hundred years in the light of analysis of cartographic materials], Badania Fizjograficzne nad Polskq Zachodniq, XXXVI, Ser. A, Geografia Fizyczna.

Helios-R y bick a E., 1986, Rola minerałów ilastych w wiązaniu metali ciżżich przez osady rzeczne górnej Wisły [The role of loamy minerals in binding of heavy metals by the river deposits of upper Vistula], Zesz. Nauk. AGH, Ser. Geologia, 32.

$\leftarrow$

Fig. 6. Contents of $\mathrm{Cd}, \mathrm{Cu}, \mathrm{Pb}$ and $\mathrm{Zn}$ in the surface part of reservoir sediments and in selected cores of deposits from the Włocławek Reservoir - the neighbourhood of Murzynowo. 
H o ok e J.M., 1977, The Distribution and Nature of Changes in River Channel Patterns: the Example of Devon, [in:] K.J. Gregory (ed.), River Channel Changes, Wiley, Chichester, 265-280.

Kajak Z., Kacprzak K., Polk owski R., 1965, Chwytacz rurowy do pobierania prób dna [Tubular bottom sampler], Ekologia polska B, 11, 2, 159-165.

Klimek K., 1994, Contamination of the Vistula River Basin Overbank Deposits by Heavy Metals. Excursions. Guide Book. $3^{\text {rd }}$ International Symposium on Environmental Geochemistry, University of Mining and Metallurgy, Kraków, 14-35.

Klimek K., 1996, Aluwia Rudy jako wskaźnik 1000-letniej degradacji Płaskowyu Rybnickiego [Alluvia of the Ruda river as the indication of the 1000-year-old degradation of the Rybnik Upland], [in:] A. Kostrzewski (ed.), Geneza, Litologia $i$ Stratygrafia Utworów Czwartorzędowych, vol. II. Wyd. UAM, 155-166.

Klimek K., Macklin M., 1991, Eksploatacja śląsko-krakowskich złóż cynku i ołowiu jako źródło metali cięzkich w aluwiach górnej Wisły [Exploitation of the SilesianCracovian deposits of zinc and lead as the source of heavy metals in the alluvia of the upper Vistula river], [in:] Geologiczne aspekty ochrony środowiska - Materiaty konferencji, Kraków, 167-171.

Koc L., 1972, Zmiany koryta Wisly w XIX i XX wieku między Płockiem a Toruniem [Changes of the Vistula river channel in the 19th and $20^{\text {th }}$ centuries between Plock and Toruń], Przegl. Geogr., 44, 4, 703-719.

S a lom on S W., 1995, Long Term Strategies for Handling Contaminated Sites and Largescale Areas, [in:] Salomons W., Stigliani W.M., Biogeodynamics of Pollutants in Soils and Sediments. Risk Assessment of Delayed and Non-Linear Responses, Springer.

S ok oł ow ska G., S z w a r c z e w s ki P., 1998, Metale ciężkie w różnowiekowych osadach aluwialnych Bzury [Heavy metals in the various age alluvial deposits of Bzura river], Przegl. Geol., 5.

Szumański A., 1982, The Evolution of the Lower San River Valley During the Late Glacial and the Holocene, Geographical Studies, Special issue No. 1.

$\mathrm{S} z$ w a r c z ew ski P., 1997, Metale cięzkie w różnowiekowych holoceńskich aluwiach Wisły okolic Torunia [Heavy metals in the various age Holocene alluvia of the Vistula river in the vicinity of Torun'], Przegl. Geol., 12.

Trafas K., 1975, Zmiany biegu koryta Wisły na wschód od Krakowa w świetle map archiwalnych $i$ fotointerpretacji [Changes of the course of the channel of Vistula river to the east of Cracow in the light of archival maps and photointerpretation], Zesz. Nauk. UJ, Prace Geogr., 40, Kraków, 85. 